\title{
PENGARUH ANALISA KESAHATAN DAN KEBANGKRUTAN DENGAN PENDEKATAN ALTMAN Z-SCORE TERHADAP HARGA SAHAM INDUSTRI KONSTRUKSI DI INDONESIA YANG LISTING DI BEI PERIODE 2013-2017
}

\author{
Abdul Kadim ${ }^{1)} \&$ Nardi Sunardi ${ }^{2)}$ \\ 1) dosen Universitas Persada Indonesia YAl, email :sak.kadim@yahoo.com \\ 2) dosen Universitas Pamulang, email : : dosen01030@unpam.ac.id
}

\section{ARTICLES}

INFORMATION

ABSTRACT

\section{JURNAL SEKURITAS \\ (Saham, Ekonomi, Keuangan dan Investasi ) \\ Vol.1, No.4, Juni 2018 \\ Halaman : 52- 65 \\ C C LPPM \& Prodi Manajemen \\ UNIVERSITAS PAMULANG \\ ISSN (online) : 2581-2777 \\ ISSN (print) : :2581-2696}

\section{Keyword :}

Altman Z-Score, Harga

Saham, Industri Konstruksi di Indonesia

JEL. classification :

C31, E50

\section{Contact Author :}

PRODI MANAJEMEN UNPAM

JL.Surya Kencana No.1 Pamulang

Tangerang Selatan - Banten

Telp. (021) 7412566, Fax (021) 7412491

Email :

jurnalfinance.unpam@gmail.com
Penelitian ini bertujuan untuk menguji pengaruh secara parsial maupun simultan antara X1, X2, X3, X4, dan X5) Dengan pendekatan Altman Z-Score terhadap Harga Saham. Populasi dalam penelitian ini adalah semua Industri Konstruksi di Indonesia yang listing di BEI periode 2013-2017 Sampel dalam penelitian ini adalah 8 Peusahaan Konstruksi sesuai dengan kriteria yang ditetapkan Analisis regresi dilakukan dengan didasarkan pada hasil analisis data panel. Penelitian ini menyimpulkan beberapa hal sebagai berikut:. (1) Variabel X1 berpengaruh positif dan signifikan terhadap Harga Saham (HS), (2) X2 berpengaruh negatif dan signifikan terhadap Harga Saham, (3) X3 berpengaruh positif dan signifikan terhadap Harga Saham, (4) X3 berpengaruh positif dan signifikan terhadap Harga Saham, (5) X5 secara parsial berpengaruh positif dan tidak signifikan terhadap Return Saham (6) X1, X2, X3, X4, dan X5) secara simultan terbukti positif dan signifikan terhadap Harga Saham (HS) Hal ini terbukti dari analisis persamaan untuk keseluruhan variabel dalam model dilakukan menggunakan uji- $F$ menunjukan nilai $F$-statistic sebesar 76.00342 dengan nilai probabilitasnya sebesar 0.0000 lebih kecil dari $\alpha=0.05$ yang berarti positif dan signifikan dengan tingkat keyakinan sebesar 0.539154 atau 53,39 persen

This study aims to test the effect of partial or simultaneous between X1, X2, X3, X4, and X5) With Altman Z-Score approach to Stock Price. Population in this research is all Construction Industry in Indonesia which listing in BEI period 2013-2017 Sample in this research is 8 Construction Company according to the criteria specified Regression analysis done by based on result of panel data analysis.. This study summarizes some of the following: (3) X3 has a positive and significant effect on Stock Price, (4) X3 has positive and significant influence on Price Shares, (5) X5 partially have positive and insignificant effect on Stock Return (6) X1, X2, X3, X4, and X5) simultaneously proved positive and significant to Share Price (HS). This is evident from the analysis of the equations for all variables in the model performed using the F-test showed F-statistic value of 76.00342 with a probability value of 0.0000 smaller than $\alpha=0.05$ which means positive and significant $\mathrm{HO}$ with a confidence level of 0.539154 or 53,39 percent 


\section{A. Pendahuluan}

Suatu kegiatan bisnis yang dilakukan oleh suatu perusahaan tentu memiliki tujuan yang ingin dicapai oleh pemilik atau pemegang perusahaan. Keuntungan perusahaan yang nantinya diperoleh merupakan suatu pencapaian target yang telah ditentukan sebelumnya. Pencapaian target sangatlah penting bagi perusahaan karena dengan pencapaian target yang telah ditetapkan atau melebihi target yang ditetapkan, hal ini merupakan prestasi tersendiri bagi pihak manajemen perusahaan. Prestasi ini merupakan ukuran untuk menilai kesuksesan dalam pengelolaan perusahaan tersebut. Demikian pula sebaliknya, apabila perusahaan gagal dalam mencapai target, hal ini merupakan cermin kegagalan manajemen dalam pengelolaan perusahaan.

Kebangkrutan perusahaan merupakan salah satu fenomena yang sering terjadi dalam dunia usaha baik dipengaruhi oleh pihak internal maupun eksternal perusahaan. Misalnya terjadi kenaikan biaya bahan baku, biaya upah, biaya listrik atau biaya lainnya tanpa diimbangi dengan kemampuan perusahaan, adanya produk pesaing yang lebih unggul sehingga mempengaruhi penjualan dan ketidakmampuan manajer dalam melakukan manajemen perusahaan.

Kejadian tersebut secara tidak langsung akan berpengaruh terhadap penurunan kinerja perusahaan dan dapat menyebabkan perusahaan mengalami kebangkrutan. Untuk mengantisipasi terjadinya kebangkrutan maka perusahaan harus mempunyai persiapan dini untuk mencegah agar tidak terjadi hal yang tidak diinginkan. Perusahaan diharapkan dapat menilai kondisi perusahaan yang sedang berjalan agar memperoleh gambaran yang lebih jelas mengenai kondisi perusahaan sekarang ini, sehingga dapat mengetahui tindakan apa yang tepat untuk mempertahankan dan memperbaiki kekurangan perusahaan agar dapat bertahan dan bersaing.

Untuk mengantisipasi terjadinya kebangkrutan maka perusahaan harus mempunyai persiapan dini untuk mencegah agar tidak terjadi hal yang tidak diinginkan. Perusahaan diharapkan dapat menilai kondisi perusahaan yang sedang berjalan agar memperoleh gambaran yang lebih jelas mengenai kondisi perusahaan sekarang ini, sehingga dapat mengetahui tindakan apa yang tepat untuk mempertahankan dan memperbaiki kekurangan perusahaan agar dapat bertahan dan bersaing.

Salah satu alat yang digunakan perusahaan untuk menilai kondisi perusahaan adalah laporan keuangan yang dihasilkan setiap periode. Agar perusahaan dapat mengetahui lebih jelas kondisi perusahaan sekarang ini, maka perusahaan dapat membandingkan laporan keuangan yang sekarang dengan laporan keuangan periode sebelumnya. Salah satu model kebangkrutan yang terbukti memberikan banyak manfaat adalah model Z-Score. Model ini dikembangkan oleh Edward I Altman seorang ekonom keuangan..

Model ini merupakan pengembangan dari teknik statistik multiple discriminant yang menggabungkan efek beberapa variabel. Model Altman ini merupakan suatu model analisis keuangan yang telah banyak digunakan di Amerika Serikat.

Analisis kebangkrutan ini sangatlah penting karena dapat menilai indikasi kebangkrutan perusahaan, apakah suatu perusahaan terancam bangkrut atau tidak, dimana bila terjadi kebangkrutan perusahaan dapat merugikan banyak pihak seperti manajer, investor, kreditor, bahkan karyawan tersebut. Berdasarkan hal yang telah disampaikan di atas kemudian peneliti merasa sangat penting untuk dapat melakukan penelitian tentang bagaimanakah indikasi kebangkrutan dengan model altman z-score pada Bank Pemerintah (BUMN) yang terdaftar di Bursa Efek Indonesia dari tahun 20122016 dan apakah model altman z-score dapat digunakan sebagai alat dalam memprediksi kecendrungan kebangkrutan perusahaan. Penelitian ini dilakukan dengan pengaruh kesahatan dan kebangkrutan dengan pendekatan altman z-score terhadap harga saham industri konstruksi di indonesia yang listing di BEI periode 2013-2017. Adapun tujuan penelitian ini: (1) Untuk mengetahui pengaruh indikasi kebangkrutan pada subsektor konstruksi di indonesia terhadap harga saham dengan model Altman z-score.; (2) Untuk 
mengetahui apakah model altman z-score dapat digunakan sebagai alat dalam memprediksi kecendrungan kebangkrutan damn kesehatan perusahaan.

Berdasarkan latar belakang diatas, maka judul penelitian ini adalah "Pengaruh Kesahatan dan Kebangkrutan dengan Pendekatan Altman Z-Score Terhadap Harga Saham Industri Konstruksi di Indonesia yang Listing di BEI Periode 2013-2017"

\section{B. Landasan teori dan Operasional Variabel \\ 1. Harga dan Return Saham}

Return merupakan hasil yng diperoleh dari investasi. Return dapat berupa return realisasian yang sudah terjadi atau return ekspektasian yang belum terjadi tetapi yang diharapkan akan terjadi da masa akan datang. Return realisasian (realized return) merupakan return yang telah tejadi. Return realisasian dihitung menggunakan data historis. Return realisasian penting karena digunakan sebagai salah satu pengukur kinerja dari perusahaan. Return realisasian atau return histori ini juga berguna sebagai dasar penentuan return ekspekstasian (expected return) dan risiko da masa akan datang.

\section{Kebangkrutan}

Perusahaan tidak selalu berjalan sesuai dengan rencana. Pada situasi tertentu, perusahaan mungkin akan mengalami kesulitan keuangan yang ringan seperti mengalami kesulitan likuiditas (tidak bisa membeyar gaji pegawai, bunga utang). Jika tidak diselesaikan dengan benar, kesulitan kecil tersebut bisa berkembang menjadi kesulitan yang lebih besar, dan bisa sampai pada kebangkrutan.

Menurut Hanafi (2008) pengertian kebangkrutan bisa dilihat dari pendekatan aliran dan pendekatan stok. Dengan menggunakan pendekatan stok, perusahaan bisa dinyatakan bangkrut jika total kewajiban melebihi total aktiva. Dengan menggunakan pendekatan aliran, perusahaan akan bangkrut jika tidak bisa menghasilkan aliran kas yang cukup. Dari sudut pandang stok, perusahaan dinyatakan bangkrut meskipun perusahaan masih dapat menghasilkan aliran kas yang cukup, atau mempunyai prospek yang baik dimasa mendatang.

\section{Masalah-Masalah Kebangkrutan}

Masalah yang timbul sehingga dapat mengakibatkan kebangkrutan yaitu, kesulitan keuangan jangka pendek yang berujung menjadi kesulitan yang tidak solvabel. Kesulitan yang tidak solvabel adalah perusahaan mengalami kesulitan dalam membayar hutang karena asset yang terbatas. Kalau tidak solvabel, perusahaan bisa dilikuidasi atau direorganisasi. Likuidasi dipilih apabila nilai likuidasi lebih besar dibandingkan dengan nilai perusahaan. Reorganisasi dipilih kalua perusahaan masih menunujukkan prospek dan dengan demikian nilai perusahaan kalua diteruskan lebih besar dibandingkan nilai perusahaan kalau dilikuidasi.

Empat variable yang menunjukkan perbedaan antara perusahaan yang bangkrut dengan yang tidak bangkrut adalah :

a. Tingkat return (rate of return). Perusahaan yang bangkrut mempunyai tingkat return yang lebih rendah.

b. Penggunaan hutang. Perusahaan yang bangkrut menggunakan hutang yang lebih tinggi.

c. Perlindungan terhadap biaya tetap (Fixed payment coverage). Perusahaan yang bangkrut mempunyai perlindungan terhadap biaya tetap yang lebih kecil.

d. Fluktuasi return saham Bank Pemerintah (BUMN) yang terdaftar di Bursa Efek Indonesia dari tahun 2012-2016 yang bangkrut mempunyai rata-rata return yang lebih rendah dan mempunyai fluktuasi return saham yang lebih tinggi.

Menurut Foster (1986) terdapat beberapa indikator atau sumber informasi mengenai kemungkinan dari kesulitan keuangan:

1. Analisis arus kas untuk periode sekarang dan yang akan datang. 
2. Analisis strategi Bank Pemerintah (BUMN) yang terdaftar di Bursa Efek Indonesia dari tahun 2012-2016 yang mempertimbangkan pesaing potensial, struktur biaya relatif, perluasan rencana dalam industri, kemampuan perusahaan untuk meneruskan kenaikan biaya, kualitas manajemen dan lain sebagainya.

3. Analisis laporan keuangan dari perusahaan serta perbandingannya dengan perusahaan lain. Analisis ini fokus pada suatu variabel keuangan tunggal atau suatu kombinasi dari variabel keuangan.

4. Informasi eksternal seperti return sekuritas dan penilaian obligasi.

\section{Teknik Analisis Data}

Analisis data yang digunakan dalam penilitian ini adalah analisis data kuantitatif yaitu suatu teknik analisis data dengan menganalisis menggunakan perhitungan angka-angka dari laporan keuangan, seperti neraca, laba rugi dan penjualan, yang kemudian digunakan sebagai dasar pengambilan keputusan. Teknik analisa yang digunakan dalam penilitian ini adalah sebagai berikut :

1. Menghitung beberapa rasio keuangan perusahaan yang terdapat dalam sampel penelitian ini,

2. Data atau hasil perhitungan rasio keuangan kemudian dianalisis dengan menggunakan formula yang ditemukan oleh Altman yaitu:

\section{$Z=1,2 X 1+1,4 X 2+3,3 X 3+0,6 X 4+1,0 \times 5$}

Sumber: Hanafi (2008:656)

Dimana:

X1 = Rasio Modal kerja terhadap total aktiva

X2 = Rasio Laba Ditahan terhadap Total Aktiva

X3 = Rasio Laba Sebelum Bunga dan Pajak terhadap Total Aktiva

X4 = Rasio Nilai Pasar Modal Saham terhadap Nilai Buku Hutang

X5 = Rasio Penjualan terhadap Total Aktiva

3. Mengklasifikasikan masing - masing sampel penelitian berdasarkan kriteria-kriteria kebangkrutan.

Kriteria-kriteria kebangkrutan menurut Altman adalah sebagai berikut:

\begin{tabular}{|c|c|c|}
\hline No. & Altman Z-Score & Predikat \\
\hline 1 & $\mathrm{Zi}>2,90$ & Sehat \\
\hline 2 & Zi diantara $1,20-2,90$ & Rawan Bangkrut (Grey Area / zone of ignorance) \\
\hline 3 & $\mathrm{Zi}<1,20$ & Bankrut \\
\hline
\end{tabular}

(Sumber : Hanafi dan Halim, 2005:274

\section{Perumusan Masalah}

Berpangkal dari latar belakang masalah seperti yang telah diuraikan diatas,

Perumusan masalah sebagai berikut :

1. Bagaimana pengaruh Rasio modal kerja terhadap total aktiva (X1) secara parsial terhadap Harga Saham (HS) ?.

2. Bagaimana pengaruh Rasio Laba Ditahan terhadap Total Aktiva (X2), secara parsial terhadap Harga Saham (HS) ?.

3. Bagaimana pengaruh Rasio Laba sebelum bunga dan pajak terhadap total aktiva (X3) secara parsial terhadap Harga Saham (HS) ?.

4. Bagaimana pengaruh Nilai Pasar Modal Saham terhadap Nilai Buku Hutang (X4) secara parsial terhadap Harga Saham (HS) ?.

5. Bagaimana pengaruh Rasio Penjualan terhadap Total aktiva (X5) secara parsial terhadap Harga Saham (HS) ?.

6. Bagaimana pengaruh $X 1, X 2, X 3, X 4, X 5$ secara simultan terhadap Harga Saham (HS) ?. 


\section{Tujuan Penelitian}

1. Untuk menganalisis dan mengetahui pengaruh Rasio modal kerja terhadap total aktiva (X1) secara parsial terhadap Harga Saham (HS) ?.

2. Untuk menganalisis dan mengetahui pengaruh Rasio Laba Ditahan terhadap Total Aktiva (X2), secara parsial terhadap Harga Saham (HS) ?.

3. Untuk menganalisis dan mengetahui pengaruh Rasio Laba sebelum bunga dan pajak terhadap total aktiva (X3) secara parsial terhadap Harga Saham (HS) ?.

4. Untuk menganalisis dan mengetahui pengaruh Nilai Pasar Modal Saham terhadap Nilai Buku Hutang (X4) secara parsial terhadap Harga Saham (HS) ?.

5. Untuk menganalisis dan mengetahui pengaruh Rasio Penjualan terhadap Total aktiva (X5) secara parsial terhadap Harga Saham (HS) ?.

6. Untuk menganalisis dan mengetahui pengaruh $X 1, X 2, X 3, X 4, X 5$ secara simultan terhadap Harga Saham (HS) ?.

\section{Kerangka Pemikiran dan Hipotesis}

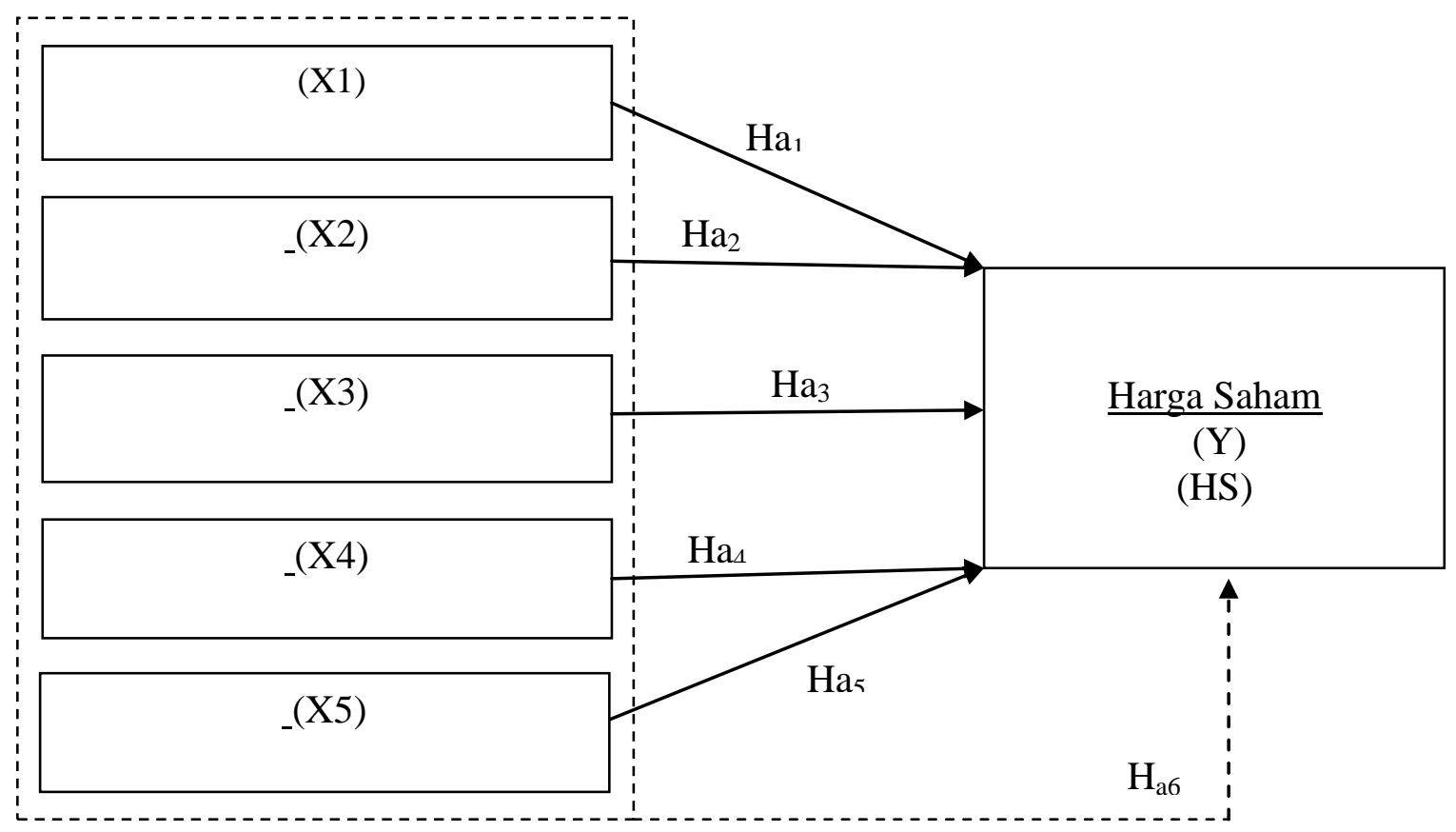

Variable

Rasio modal kerja terhadap total aktiva

Rasio Laba Ditahan terhadap Total Aktiva

Rasio Laba sebelum bunga dan pajak terhadap total aktiva

Nilai Pasar Modal Saham terhadap Nilai Buku Hutang

\section{$\begin{array}{ll}\text { Proxy Measurement } & \text { Mex }\end{array}$}

$\mathrm{X} 1$

$\mathrm{X} 2$

$$
\mathrm{X} 1=\frac{\text { Modal Kerja }}{\text { Total Aktiva }}
$$$$
\text { X2 }=\frac{\text { Laba ditahan }}{\text { Total Aktiva }}
$$

$\mathrm{X} 3$

$$
\mathrm{X} 3=\frac{\mathrm{EBIT}}{\text { Total Aktiva }}
$$

$\mathrm{X} 4$

$$
\text { X4 }=\frac{\text { Nilai Pasar Modal }}{\text { Nilai Buku Hutang }}
$$


Rasio Penjualan terhadap Total aktiva
$\mathrm{X} 5$

$$
\text { X5 }=\frac{\text { Penjualan }}{\text { Total Aktiva }}
$$

\section{Hipotesis Penelitian}

$\mathrm{Ha}_{1}$ : $X 1$ berpengaruh terhadap Harga Saham (HS)

$\mathrm{Ha}_{2}$ : X2 berpengaruh terhadap Harga Saham (HS)

$\mathrm{Ha}_{3}$ : X3 berpengaruh terhadap Harga Saham (HS)

$\mathrm{Ha}_{4}$ : X4 berpengaruh terhadap Harga Saham (HS)

$\mathrm{Ha}_{5}$ : X4 berpengaruh terhadap Harga Saham (HS)

$\mathrm{Ha}_{6} \quad: X 1, X 2, X 3, X 4, X 5$ berpengaruh terhadap Return Saham (HS)

\section{F. Metodologi Penelitian}

Jenis Penelitian ini menggunakan pendekatan kuantitatif yang merupakan masingmasing variabel maupun antar variabel didasari pada skala pengukuran kuantitatif.

Populasi dan sampel dalam penelitian ini di Bursa Efek Indonesia periode 2013-2017 Populasi dalam penelitian ini adalah perusahaan pada Industri Konstruksi di Indonesia yang Listing di Bursa Efek Indonesia periode 2013-2017 dan situs internet www.idx.co.id.

Penarikan sampel yang dilakukan adalah dengan menggunakan desain sampel non probabilitas dengan metode judgment sampling. Judgment sampling adalah salah satu jenis purposive sampling dimana dilakukan pemilihan sampel berdasarkan penilaian terhadap beberapa karakteristik anggota populasi yang disesuaikan dengan maksud penelitian (Kuncoro, 2003:119). Kriteria penarikan sampel yang digunakan adalah :

Kriteria penarikan sampel yang digunakan oleh peneliti adalah :

\begin{tabular}{clc}
\hline No. & \multicolumn{1}{c}{ Karakteristik Sampel } & $\begin{array}{c}\text { Jumlah } \\
\text { Sampel }\end{array}$ \\
\hline 1 & $\begin{array}{l}\text { Jumlah populasi adalah perusahaan yang bergerak pada sektor } \\
\text { Industri Konstruksi di Indonesia yang Listing di Bursa Efek Indonesia } \\
\text { periode 2013-2017 }\end{array}$ & 9 \\
\hline 2. & $\begin{array}{l}\text { Perusahaan Konstruksi di Indonesia yang tidak memiliki laporan } \\
\text { keuangan lengkap serta tidak mempublikasikan data harga saham }\end{array}$ & $(1)$ \\
secara lengkap selama 5 tahun & $\mathbf{8}$ \\
\hline Jumlah Sampel Akhir & $\mathbf{5}$ \\
Tahun Pengamatan & $\mathbf{4 0}$ \\
\hline
\end{tabular}

Sampel Penelitian sbb :

\begin{tabular}{ccl} 
No. & Kode & \multicolumn{1}{c}{ Perusahaan Konstruksi di Indonesia } \\
\hline 1 & ADHI & PT.Adhi Karya (Persero) Tbk \\
2 & PTPP & PT. PP (Persero) Tbk \\
3 & WIKA & PT.Wijaya Karya (Persero) Tbk \\
4 & WSKT & PT. Waskita Karya (Persero) Tbk \\
5 & ACST & PT. Acset Indonusa Tbk \\
6 & DGIK & PT. Nusa Konstruksi Enjiniring Tbk \\
7 & NRCA & PT.Nusa Raya Cipta Tbk \\
8 & TOTL & PT. Total Bangun Persada Tbk \\
\hline
\end{tabular}

Sumber : Hasil diolah 2018 


\section{G. Hasil dan Pembahasan}

Penelitian ini melakukan estimasi terhadap $X 1, X 2, X 3, X 4, X 5$ secara simultan terhadap Harga Saham (HS) perusahaan Industri Konstruksi di Indonesia yang Listing di Bursa Efek Indonesia periode 2013-2017

Hasil Altman Z-Score Industri Konstruksi di Indonesia yang Listing di Bursa Efek Indonesia periode 2013-2017 menunjukkan bahwa rata-rata Kebangkrutan sebagai berikut :

Kebangkrutan pada Industri Konstruksi di Indonesia yang Listing di Bursa Efek Indonesia periode 2013-2017

\begin{tabular}{|c|c|c|c|c|c|c|c|c|}
\hline \multirow{2}{*}{ No } & \multirow{2}{*}{$\begin{array}{c}\text { Nama Perusahaan } \\
\text { Konstruksi }\end{array}$} & \multicolumn{5}{|c|}{ Analisa Altman Z-Score } & \multirow{2}{*}{ Rata $^{2}$} & \multirow{2}{*}{ Kriteria } \\
\hline & & 2012 & 2013 & 2014 & 2015 & 2016 & & \\
\hline 1 & $\begin{array}{l}\text { PT.Adhi Karya } \\
\text { (Persero) Tbk }\end{array}$ & $24.5 \%$ & $11.2 \%$ & $4.4 \%$ & $119.9 \%$ & $69.7 \%$ & $201 \%$ & $\begin{array}{c}\text { Rawan } \\
\text { Bangkrut }\end{array}$ \\
\hline 2 & $\begin{array}{l}\text { PT. PP (Persero) } \\
\text { Tbk }\end{array}$ & $25.4 \%$ & $9.7 \%$ & $5.8 \%$ & $65.8 \%$ & $69.0 \%$ & $172 \%$ & $\begin{array}{l}\text { Rawan } \\
\text { Bangkrut }\end{array}$ \\
\hline 3 & $\begin{array}{l}\text { PT.Wijaya Karya } \\
\text { (Persero) Tbk }\end{array}$ & $13.9 \%$ & $9.6 \%$ & $5.6 \%$ & $85.0 \%$ & $69.9 \%$ & $170 \%$ & $\begin{array}{c}\text { Rawan } \\
\text { Bangkrut }\end{array}$ \\
\hline 4 & $\begin{array}{l}\text { PT. Waskita Karya } \\
\text { (Persero) Tbk }\end{array}$ & $24.4 \%$ & $6.5 \%$ & $5.2 \%$ & $95.6 \%$ & $64.8 \%$ & $178 \%$ & $\begin{array}{c}\text { Rawan } \\
\text { Bangkrut }\end{array}$ \\
\hline 5 & $\begin{array}{l}\text { PT. Acset Indonusa } \\
\text { Tbk }\end{array}$ & $26.5 \%$ & $18.5 \%$ & $5.4 \%$ & $62.3 \%$ & $73.8 \%$ & $187 \%$ & $\begin{array}{c}\text { Rawan } \\
\text { Bangkrut }\end{array}$ \\
\hline 6 & $\begin{array}{l}P T . \text { Nusa } \\
\text { Konstruksi } \\
\text { Enjiniring Tbk }\end{array}$ & $18.3 \%$ & $19.0 \%$ & $-2.2 \%$ & $65.8 \%$ & $76.0 \%$ & $157 \%$ & $\begin{array}{c}\text { Rawan } \\
\text { Bangkrut }\end{array}$ \\
\hline 7 & $\begin{array}{l}\text { PT.Nusa Raya } \\
\text { Cipta Tbk }\end{array}$ & $34.3 \%$ & $23.8 \%$ & $10.6 \%$ & $96.4 \%$ & $\begin{array}{c}150.7 \\
\%\end{array}$ & $318 \%$ & Sehat \\
\hline 8 & $\begin{array}{l}\text { PT. Total Bangun } \\
\text { Persada Tbk }\end{array}$ & $32.6 \%$ & $19.0 \%$ & $8.7 \%$ & $58.0 \%$ & $82.6 \%$ & $212 \%$ & $\begin{array}{c}\text { Rawan } \\
\text { Bangkrut }\end{array}$ \\
\hline \multicolumn{7}{|c|}{ Tingkat Kebangkrutan Perusahaan Konstruksi } & $180 \%$ & $\begin{array}{c}\text { Rawan } \\
\text { Bangkrut }\end{array}$ \\
\hline
\end{tabular}

Sumber: Data diolah (2018)

Setelah dilakukan perhitungan terhadap masing-masing variabel (X1, X2, X3, X4, X5) dalam empat tahun berturut-turut sehingga dapat diketahui rata-rata Z-Score pada Perusahaan Konstruksi di Indonesia sebesar 180\%, Hal ini menunujukkan bahwa kondisi Perusahaan Konstruksi di Indonesia secara keseluruhan tidak berpotensi kebangkrutan dan Rawan Bangkrut.

Terdapat 7 perusahaan yang masuk dalam kategori rawan bangkrut atau bisa dikatakan Perusahaan Konstruksi yang berpotensi kebangkrutan, yakni PT.Adhi Karya (Persero) Tbk), PT. PP (Persero) Tbk, PT.Wijaya Karya (Persero) Tbk, PT. Acset Indonusa Tbk, PT. Nusa Konstruksi Enjiniring Tbk dan PT. Total Bangun Persada Tbk. Hanya satu perusahaan yang dikatakan sehat yaitu PT.Nusa Raya Cipta Tbk. Hal ini menunjukkan bahwa perusahaan harus lebih memfokuskan pada usaha perbaikan kinerja perusahaan untuk meningkatkan kelima rasio tersebut, misalnya yaitu dengan meningkatkan volume penjualan terhadap persediaan yang ada, sehingga ada pemasukan pada kas perusahaan dari hasil penjualan tersebut. Selain memperbaiki dari segi keuangan perusahaan namun perusahaan juga dapat dengan memperbaiki dan menambah asset tidak berwujud (Intangible Assets) yang dimiliki oleh perusahaan. Intangible Assets ini diantaranya adalah sistem manajemen perusahaan, pinjaman (Loan) dari pihak kedua baik bank maupun perusahaan lain, bantuan dari pemerintah (subsidiary), perjanjian kontrak kerjasama dengan perusahaan ternama. Melihat kondisi diatas, maka pengelola harus lebih berhati-hati dan harus melakukan perbaikan secepatnya. 


\section{Deskripsi Data Statistik}

Deskripsi data statistik data yang diinput dari Bursa Efek Indonesia (IDX) maka dapat dihitung rasio-rasio keuangan yang digunakan dalam penelitian ini yang meliputi $X 1, X 2, X 3, X 4, X 5$ Selanjutnya apabila dilihat dari nilai minimum, maksimum, ratarata (mean) dan standar deviasi $(\delta)$ dari masing-masing variabel penelitian dapat dilihat pada tabel berikut ini:

\section{Deskripsi Data Statistik}

\begin{tabular}{|c|c|c|c|c|c|c|}
\hline & HS & $\mathbf{X 1}$ & $\mathrm{X} 2$ & $\mathbf{X 3}$ & $\mathbf{X 4}$ & $\mathrm{X5}$ \\
\hline Mean & 1805.650 & 0.249825 & 0.134050 & 0.054475 & 0.811100 & 0.820000 \\
\hline Median & 2080.000 & 0.263500 & 0.107500 & 0.056500 & 0.603500 & 0.760000 \\
\hline Maximum & 3810.000 & 0.482000 & 0.291000 & 0.207000 & 2.732000 & 1.850000 \\
\hline Minimum & 55.00000 & 0.039000 & -0.030000 & -0.241000 & 0.008000 & 0.390000 \\
\hline Std. Dev. & 1179.070 & 0.097292 & 0.073108 & 0.061558 & 0.754928 & 0.344733 \\
\hline Skewness & -0.059266 & -0.304448 & 0.188167 & -2.277009 & 0.929947 & 1.676958 \\
\hline Kurtosis & 1.713282 & 3.079199 & 2.779819 & 15.35244 & 2.937218 & 5.846115 \\
\hline Jarque-Bera & 2.782820 & 0.628377 & 0.316844 & 288.8698 & 5.771909 & 32.24853 \\
\hline Probability & 0.248724 & 0.730381 & 0.853489 & 0.000000 & 0.055801 & 0.000000 \\
\hline Sum & 72226.00 & 9.993000 & 5.362000 & 2.179000 & 32.44400 & 32.80000 \\
\hline Sum Sq. Dev. & 54218043 & 0.369162 & 0.208446 & 0.147788 & 22.22672 & 4.634800 \\
\hline Observations & 40 & 40 & 40 & 40 & 40 & 40 \\
\hline Cross sections & 8 & 8 & 8 & 8 & 8 & 8 \\
\hline
\end{tabular}

\section{Pemilihan Model Regresi Data Panel untuk faktor-faktor yang memepengaruhi Harga Saham (HS)}

Permodelan dalam mengunakan teknik regresi data panel yang digunakan dalam penelitian ini dapat menggunakan tiga pendekatan alternative metode regresi data panel dalam pengolahannya yaitu (1) metode common-constant (the pooled ordinary least square model (OLS), (2) metode efek tetap (fixed effect model (FEM), dan (3) metode efek random (random effect model (REM). Berikut merupakan aplikasi dari pemilihan model yang ditetapkan terhadap faktor-faktor yang memepengaruhi Harga Saham (HS)

\section{Uji berpasangan dua model}

Berdasarkan pengujian berpasangan terhadap ketiga model regresi data panel, seperti yang ditunjukan dalam tabel diatas terdapat disimpulkaan bahwa model efek tetap dalam regresi data panel digunakan lebih lanjut dalam mengestimasi faktor-faktor yang memepengaruhi Harga Saham (HS)

Kesimpulan Pengujian Model Regresi Data Panel

\begin{tabular}{|c|l|l|l|}
\hline No & \multicolumn{1}{|c|}{ Metode } & \multicolumn{1}{c|}{ Pengujian } & \multicolumn{1}{c|}{ Hasil } \\
\hline 1. & Uji Chow-Test & common effect vs fixed effect & common effect \\
\hline 2. & Langrage Multiplier (LM-test) & common effect vs random effect & common effect \\
\hline 3. & Haustman Test & fixed effect vs random effect & fixed effect \\
\hline
\end{tabular}

\section{Hasil Analisis Estimasi Model Regresi Data Panel faktor-faktor yang memepengaruhi Harga Saham (HS)}

Berdasarkan hasil estimasi yang terbaik menggunakan kriteria koefisien diterminasi $R^{2}$ dan koefisien diterminasi yang disesuaikan $R^{2}$, maka model regresi data panel yang digunakan dalam menestimasi faktor-faktor yang memepengaruhi Harga 
Saham (HS) yang tergabung dalam perusahaan pada Industri Konstruksi di Indonesia yang Listing di Bursa Efek Indonesia periode 2013-2017 adalah model efek common

\section{Estimasi Model Regresi Data Panel secara Parsial (Uji T) dan Simultan (Uji F) Variable Dependen Harga Saham (HS).}

Hasil estimasi faktor yang mempengaruhi Harga Saham (HR) yaitu, $X 1, X 2, X 3$, $X 4, X 5$ sebagai variable terikat (depedent variable) mengunakan model efek common seperti yang ditunjukan dalam tabel berikut ini :

Dependent Variable: HS?

Method: Pooled EGLS (Cross-section weights)

Date: 05/28/18 Time: 05:22

Sample: 20132015

Included observations: 3

Cross-sections included: 8

Total pool (balanced) observations: 24

Linear estimation after one-step weighting matrix

\begin{tabular}{rrrrr}
\hline \multicolumn{1}{c}{ Variable } & Coefficient & Std. Error & t-Statistic & Prob. \\
\hline X1? & 5674.650 & 1520.377 & 3.732396 & 0.0014 \\
X2? & -9985.155 & 3727.976 & -2.678439 & 0.0149 \\
X3? & 18012.83 & 3821.392 & 4.713682 & 0.0002 \\
X4? & 1357.253 & 374.2479 & 3.626615 & 0.0018 \\
X5? & 58.57236 & 709.5040 & 0.082554 & 0.9351 \\
\hline \hline & Weighted Statistics & & \\
\hline \hline R-squared & 0.539154 & Mean dependent var & 1889.850 \\
Adjusted R-squared & 0.442134 & S.D. dependent var & 1381.887 \\
S.E. of regression & 1092.702 & Sum squared resid & 22685951 \\
F-statistic & 76.00342 & Durbin-Watson stat & 2.971719 \\
Prob(F-statistic) & 0.000000 & & & \\
\hline \hline & Unweighted Statistics & & \\
\hline \hline
\end{tabular}

Hasil Regresi data panel menggunakan Common Effect sbb :

\begin{tabular}{|c|c|c|c|c|}
\hline Model & Adjusted $R^{2}$ & Prob. (F-stat.) $\alpha-0,05$ & \multicolumn{2}{|c|}{ Probabilitas $\alpha-0,05$} \\
\hline \multirow{5}{*}{$\begin{array}{c}\text { Commond } \\
\text { Effect }\end{array}$} & \multirow{5}{*}{0.442134} & \multirow{5}{*}{0.0000} & $\mathrm{X} 1$ & Signifikan \\
\hline & & & $\mathrm{X} 2$ & Signifikan \\
\hline & & & X3 & Signifikan \\
\hline & & & X4 & Signifikan \\
\hline & & & $\times 5$ & Tidak Sigifikan \\
\hline
\end{tabular}




\section{Uji T (Uji Signifikasi Parsial) Variable Dependen Harga Saham (HS).}

Uji keberartian koefisien ( $\beta i)$ dilakukan dengan statistik t. Hal ini digunakan untuk menguji koefisien regresi secara parsial dari variabel independen (mengetahui apakah masing-masing variabel independen secara signifikan berpengaruh terhadap variabel dependen).

- Uji T (parsial) Hipotesis 1 Rasio modal kerja terhadap total aktiva (X1) terhadap Harga Saham.

Uji signifikansi atau uji-t yang dilakukan pada variabel bebas dapat dilihat dari nilai koefisien regresi dibagi Std. Error $=t$-statstic. Berdasarkan uji-t menunjukan bahwa variable $X 1$ dengan koefisien regresi $\beta_{1}$ sebesar 5674.650 dan $t$-statistic sebesar 3.732396 yang menunjukkan bahwa pengaruh tersebut adalah positif. Hasil uji $t$ dapat dilihat pada tabel di atas. Nilai prob. $t_{\text {hitung }}$ sebesar 0.0014 (ditunjukkan pada Prob.) lebih kecil dari tingkat kesalahan (alpha) 0,05 (yang telah ditentukan) maka dapat dikatakan signifikan. Hipotesis variabel bebas yaitu $X 1$ yang diajukan diterima atau dikatakan berpengaruh positif dan signifikan terhadap variabel terikat yaitu Harga Saham dengan demikian variabel $X 1$ mempengruhi Harga Saham perusahaan yang tergabung dalam perusahaan pada Industri Konstruksi di Indonesia yang Listing di Bursa Efek Indonesia periode 2013-2017 Interpretasi nya dari uji kelayakan memastikan bahwa jika perusahaan menaikan $X 1$ sebesar 1 persen maka akan meningkatkan Harga Saham sebesar 3.732396 dengan nilai signifikan. Begitu pula sebaliknya.

- Uji T (parsial) Hipotesis 2 Rasio Laba Ditahan terhadap Total Aktiva (X2) terhadap Harga Saham.

Uji signifikansi atau uji-t yang dilakukan pada variabel bebas dapat dilihat dari nilai koefisien regresi dibagi Std. Error $=t$-statstic. Berdasarkan uji-t menunjukan bahwa variable $X 2$ dengan koefisien regresi $\beta_{1}$ sebesar -9985.155 dan $t$-statistic sebesar 2.678439 yang menunjukkan bahwa pengaruh tersebut adalah negatif. Hasil uji $t$ dapat dilihat pada tabel di atas. Nilai prob. $t$ hitung sebesar 0.0149 (ditunjukkan pada Prob.) lebih besar dari tingkat kesalahan (alpha) 0,05 (yang telah ditentukan) maka dapat dikatakan tidak signifikan. Hipotesis variabel bebas yaitu $X 2$ yang diajukan tidak diterima atau dikatakan berpengaruh negatif dan signifikan terhadap variabel terikat yaitu Harga Saham dengan demikian variabel X2 mempengruhi Harga Saham perusahaan pada Industri Konstruksi di Indonesia yang Listing di Bursa Efek Indonesia periode 2013-2017. Interpretasi nya dari uji kelayakan memastikan bahwa jika perusahaan menaikan $X 2$ sebesar 1 persen maka akan menurunkan Harga Saham sebesar 2.678439 dengan nilai signifikan. Begitu pula sebaliknya.

- Uji T (parsial) Hipotesis 3 Rasio Laba sebelum bunga dan pajak terhadap total aktiva (X3) terhadap Harga Saham.

Uji signifikansi atau uji-t yang dilakukan pada variabel bebas dapat dilihat dari nilai koefisien regresi dibagi Std. Error $=t$-statstic. Berdasarkan uji-t menunjukan bahwa variable $X 3$ dengan koefisien regresi $\beta_{1}$ sebesar 18012.83 dan $t$-statistic sebesar 4.713682 yang menunjukkan bahwa pengaruh tersebut adalah positif. Hasil uji $t$ dapat dilihat pada tabel di atas. Nilai prob. $t_{\text {hitung }}$ sebesar 0.0002 (ditunjukkan pada Prob.) lebih kecil dari tingkat kesalahan (alpha) 0,05 (yang telah ditentukan) maka dapat dikatakan signifikan. Hipotesis variabel bebas yaitu $X 3$ yang diajukan diterima atau dikatakan berpengaruh positif dan signifikan terhadap variabel terikat yaitu Harga Saham dengan demikian variabel X3 mempengruhi Harga Saham perusahaan pada Industri Konstruksi di Indonesia yang Listing di Bursa Efek Indonesia periode 2013-2017. Interpretasi nya dari uji kelayakan memastikan bahwa jika perusahaan menaikan $X 3$ sebesar 1 persen maka akan meningkatkan Harga Saham sebesar 4.120242 dengan nilai signifikan. Begitu pula sebaliknya. 
- Uji T (parsial) Hipotesis 4 Nilai Pasar Modal Saham terhadap Nilai Buku Hutang (X4) terhadap Harga Saham.

Uji signifikansi atau uji-t yang dilakukan pada variabel bebas dapat dilihat dari nilai koefisien regresi dibagi Std. Error $=t$-statstic. Berdasarkan uji-t menunjukan bahwa variable $X 4$ dengan koefisien regresi $\beta_{1}$ sebesar 1357.253 dan $t$-statistic sebesar 3.626615 yang menunjukkan bahwa pengaruh tersebut adalah positif. Hasil uji t dapat dilihat pada tabel di atas. Nilai prob. $t_{\text {hitung }}$ sebesar 0.0018 (ditunjukkan pada Prob.) lebih kecil dari tingkat kesalahan (alpha) 0,05 (yang telah ditentukan) maka dapat dikatakan signifikan. Hipotesis variabel bebas yaitu $X 4$ yang diajukan diterima atau dikatakan berpengaruh positif dan signifikan terhadap variabel terikat yaitu Harga Saham dengan demikian variabel X4 tidak mempengruhi Harga Saham perusahaan pada Industri Konstruksi di Indonesia yang Listing di Bursa Efek Indonesia periode 2013-2017. Interpretasi nya dari uji kelayakan memastikan bahwa jika perusahaan menaikan $X 4$ sebesar 1 persen maka akan menaikkan Harga Saham sebesar 3.626615 dengan nilai signifikan. Begitu pula sebaliknya.

- Uji T (parsial) Hipotesis 5 Rasio Penjualan terhadap Total aktiva (X5) terhadap Harga Saham.

Uji signifikansi atau uji-t yang dilakukan pada variabel bebas dapat dilihat dari nilai koefisien regresi dibagi Std. Error $=t$-statstic. Berdasarkan uji-t menunjukan bahwa variable $X 5$ dengan koefisien regresi $\beta_{1}$ sebesar 58.57236 dan $t$-statistic sebesar 0.082554 yang menunjukkan bahwa pengaruh tersebut adalah positif. Hasil uji $\mathrm{t}$ dapat dilihat pada tabel di atas. Nilai prob. $t_{\text {hitung }}$ sebesar 0.9351 (ditunjukkan pada Prob.) lebih besar dari tingkat kesalahan (alpha) 0,05 (yang telah ditentukan) maka dapat dikatakan tidak signifikan. Hipotesis variabel bebas yaitu $X 5$ yang diajukan diterima atau dikatakan berpengaruh positif dan tidak signifikan terhadap variabel terikat yaitu Harga Saham dengan demikian variabel $X 5$ tidak mempengruhi Harga Saham perusahaan pada Industri Konstruksi di Indonesia yang Listing di Bursa Efek Indonesia periode 2013-2017. Interpretasi nya dari uji kelayakan memastikan bahwa jika perusahaan menaikan $X 5$ sebesar 1 persen maka akan menaikkan Harga Saham sebesar 0.082554 dengan nilai tidak signifikan. Begitu pula sebaliknya.

\section{Uji F (Uji Signifikasi Simultan) Variable Dependen Harga Saham (HS)}

Uji keterandalan model atau uji kelayakan model atau yang lebih populer disebut sebagai uji $f$ (uji simultan) merupakan tahapan awal mengidentifikasi model regresi data panel yang diestimasi layak atau tidak. Layak (andal) disini maksudnya adalah model yang diestimasi layak digunakan untuk menjelaskan pengaruh variabel-variabel bebas terhadap variabel terikat. Nama uji ini disebut sebagai uji $\mathrm{f}$, karena mengikuti mengikuti distribusi f yang kriteria pengujiannya seperti One Way Anova.

- Uji F (simultan) Hipotesis 6 Pengaruh X1, X2, X3, X4, X5 secara bersama-sama (simultan) terhadap Harga Saham (HR) .

Berdasarkan Uji koefisien regresi data panel menggunakan uji-f (simultan) pengujian persamaan untuk keseluruhan variable dalam model dilakukan menggunakan uji-f. hasil pengujian $f$ seperti yang terlihat dalam tabel diatas menunjukan nilai f-statistic sebesar 76.00342 menunjukan hasil positif. dengan nilai probabilitasnya sebesar 0,00000 lebih kecil dari $\alpha=0,05$ yang berarti hipotesis yang diajukan layak dan dikatakan signifikan. Dalam menghitung nilai koefisien determinasi menggunakan $R$-Square daripada Adjusted $R$-Square. Walaupun variabel bebas lebih dari satu. menujukkan angka sebesar 0.539154 artinya bahwa variasi perubahan naik turunnya determinan Harga Saham perusahaan berkontribusi dan dapat dijelaskan oleh variabel $X 1, X 2, X 3, X 4, X 5$ sebesar $53,39 \%$ sedangkan sisanya $46.61 \%(100 \%-53,39 \%)$ dipengaruhi oleh variabel lain yang tidak ada 
didalam model regresi data panel dalam penelitian ini, berarti bahwa seluruh variable indepeden yang digunakan dalam penelitian ini dapat menjelaskan Harga Saham perusahaan sebesar 53,39 persen.

\section{H. Kesimpulan}

1. Rasio modal kerja terhadap total aktiva (X1) secara parsial berpengaruh positif dan signifikan terhadap Harga Saham (HS)

2. Rasio Laba Ditahan terhadap Total Aktiva (X2) secara parsial berpengaruh negatif dan signifikan terhadap Harga Saham (HS)

3. Rasio Laba sebelum bunga dan pajak terhadap total aktiva (X3) secara parsial berpengaruh positif dan signifikan terhadap Harga Saham (HS)

4. Rasio Laba sebelum bunga dan pajak terhadap total aktiva (X3) secara parsial berpengaruh positif dan signifikan terhadap Harga Saham (HS)

5. Rasio Penjualan terhadap Total aktiva (X5) secara parsial berpengaruh positif dan tidak signifikan terhadap Return Saham (RS)

6. $X 1, X 2, X 3, X 4$, dan $X 5)$ secara simultan terbukti positif dan signifikan terhadap Harga Saham (HS)

\section{Daftar Pustaka}

Abdul Kadim \& Nardi Sunardi (2018), "Analisis Altman Z-Score Untuk Memprediksi Kebangkrutan Pada Bank Pemerintah (BUMN) di Indonesia Tahun 2012-2016", Jurnal Sekuritas (Saham, Ekonomi, Keuangan dan Investasi) ISSN (online) : 25812777 ISSN (print) : 2581-2696, Vol.1, No.3, Maret 2018, Hal. : 142 - 156, Universitas Pamulang.

Adnan, K. M. dan E. Kurnayasih. 2000. Analisis Tingkat Kesehatan Perusahaan untuk Memprediksi Potensi Kebangkrutan pada Pendekatan Altman. Jurnal Akuntansi dan auditing Indonesia 4(2): 131-149. Bankcrupty. Journal of Finance 23 (4): 589-609.

Albertha W. Hutapea, Ivonne S. Saerang Joy E. Tulung (2017) Pengaruh Return On Assets, Net Profit Margin, Debt To Equity Ratio, Dan Total Assets Turnover Terhadap Harga Saham Industri Otomotif Dan Komponen Yang Terdaftar Di Bursa Efek Indonesia, Jurnal EMBA, Vol.5 No.2 Juni 2017, Hal. 541 - 552, Universitas Sam Ratulangi Manado.

Altman, E. I. 1968. Financial Ratios, Discriminant Analysis and the Prediction of Corporate

Bambang Juanda, (2009). Ekonometrika Permodelan dan Pendugaan cetakan pertama: Februari 2012 Bogor: Penerbit IPB Press PT.

Bambang Juanda, Junaidi (2012). Ekonometrika Deret \& Waktu, Teori \& Aplikasi cetakan petama: Juni 2012 Bogor: Penerbit IPB Press PT.

Bank Indonesia (2015), Tinjauan Kebijakan Moneter Desember 2015

Bapenas (2016) Badan Perencanaan Nasional Republik Indonesia, Peraturan Presiden RKP 2016

Brigham \& Houston. (2010) Dasar - Dasar Manajemen Keuangan (Essentials Of Financial Management). Edisi ke - 11. Salemba Empat. Jakarta. (Diterjemahkan oleh Ali Akbar Yulianto).

Brigham \& Houston. (2013). Essential of Financial Management. Original edition first published by Cengage Learning 2007,Diterjemahkan oleh: Ali Akbar Yulianto. 2011. Dasar-dasar Manajemen Keuangan. Buku 1-2 Jakarta: Salemba Empat.

Certo Samuel C.\& Certo S. Trevis (2009). Modern Managerial Concept and Skills $11^{\text {th }}$ Edition. England: Person international Edition 2009 
Chen, Guo \& Mande (2006), "Corporate Value, Managerial Stockholdings and Investment of Japanese Firms". Journal of International Financial Management and Accounting. Vol.17:1, pp. 29-51.

Dewi Utari, Purwanti A, Prawironegoro D. (2014). Manajemen Keuangan; Kajian Praktik dan Teori dalam Mengelola Keuangan Organisasi Perusahaan. Edisi Revisi 2014. Jakata: Mitra Wacana Media.

Eko Priyanto dan Dheasey A. (2016) Analisis Du Pont System Untuk Menilai Kinerja Keuangan Perusahaan (Studi Pada PT. Mayora Indah Tbk, PT. Delta Djakarta Tbk, dan PT. Indofood Sukses Makmur Tbk Periode Tahun 2010-2015) Fakultas Ekonomika dan Bisnis Universitas Pandanaran.

Ferbianasari, H. N. (2011). Analisis Penilaian Financial Distress Menggunakan Model Altman (Z-Score) Pada Perusahaan Kosmetik Yang Tercatat Di Bursa Efek Indonesia. Skripsi. Fakultas Ekonomi Universitas Negeri Surabaya. Surabaya

Gilrita, Moch. Dzulkirom dan M.G Wi Endang N.P (2015), "Analisis Altman (Z-Score) Sebagai Salah Satu Cara untuk Mengukur Potensi Kebangkrutan Perusahaan (Studi Pada Perusahaan Manufaktur yang Listing di BEI dan Perusahaan Manufaktur yang Delisting dari BEI Periode 2012-2014)", Jurnal Administrasi Bisnis (JAB) Vol. 25 No. 1 Agustus 2015, Fakultas Ilmu Administrasi, Universitas Brawijaya.

Gujarati Damodar N, Forter Dawn C. (2013). Basic Econometrics, $5^{\text {th }}$ Edition. Diterjemahkan oleh: Eugenia Mardanugraha, Sita Mardani, Carlos Mangunsong. (2013). Dasar-dasar Ekonometrika. Jakarta: Salemba Empat.

Hady Hamdy, (2012). Keuangan Internasional . edisi 3 Jakarta: Mitra Wacana Media.

Iswi Handayani \& Serfianto (2010). Buku Pintar Hukum Bisnis Pasar Modal Indonesia, Strategi Tepat investasi Saham,Obligasi, Waran, Right, Opsi, Reksadana, dan Produk Pasar Modal Syariah, Visimedia, Jakarta.

J. Suprapto, Nandan Limakrisna. (2013). Petunjuk Praktis Penelitian IImiah untuk Menyusun Skripsi Tesis dan Disertasi Edisi 3. Jakarta: Mitra Wacana Media.

Jensen \& Meckling (1976), Agency Theory, Theory of the firm, Managerial behavior, Agency Costs and Ownership Structure, Journal of Financial Economics, October, 1976, V. 3, No. 4, pp. 305-360,also published in Foundations of Organizational Strategy, Michael C. Jensen, Harvard University Press, 1998.

Jessica L. Matondang dan Rahmawati HY (2015) analisis empiris yang mempengaruhi nilai perusahan, Sekolah Tinggi IImu Ekonomi Y.A.I - Indonesia

Keown AJ, Martin JD, Fetty JW, Scott, JR DF (2010). Financial Management: Priciples and Applications $10^{\text {th }}$ Edition. Diterjemahkan oleh: Marcus Priminto Widodo, M.A. 2010. Manajemen Keuangan; Prinsip dan Penerapan. Jakarta: PT Indeks.

Lipsesy Richard G, Stainer Peter. (2014). Economics Sixth Edition. Harper International Edition NewYork.

Mansuri (2016). Buku Modul Praktikum Eviews Universitas Borobudur

Modigliani F. \& Miller M. (1958) MM Theory, The Cost of Capital, Corporation Finance, and The Theory of Invesment, The American economic Revlew Volume XIVIII June 1958 No. 3, pp. 261-297

Myers \& Majluf (1984), Pecking order theory, Corporate Financing and Investment Decisions When Firms Have Information That Investors Do Not Have, Journal of Financial Economics, Vol 13, pp.187-221.

Nachrowi dan H. Usman. (2006). Pendekatan Populer dan Praktis Ekonometruka untuk Analisis Ekonomi dan Keuangan, Lembaga Penerbit Universitas Indonesia, Jakarta.

Nardi Sunardi (2017) Determinan Kebijakan Utang Serta Implikasinya terhadap Kinerja Perusahaan (Perusahaan yang tergabung dalam indeks LQ.45 yang terdaftar di Bursa Efek Indonesia Tahun 2011- 2015) Jurnal Sekuritas, Vol. 1, No.1/ September 2017 Universitas Pamulang. 
Nardi Sunardi, Aceng Abdul Hamid, Lativa, Abdul Kadim, Natanael Tulus (2018) Determinant Of Cost Efficiency And It's Implications For Companies Performance Incorporated In The Lq.45 Index Listing In Idx For The Period of 2011-2016, International Journal of Applied Business and Economic Research,. Volume 16, Number 1, 2018, ISSN : 0972-7302

NMDP. Saraswati, Topowijono \& Fransisca Y. (2015), Analisis Du Pont System Sebagai Salah Satu Alat Mengukur Kinerja Keuangan Perusahaan (Studi pada Perusahaan Rokok yang Listing di Bursa Efek Indonesia Tahun 2011-2013), Jurnal Administrasi Bisnis (JAB), Vol. 23 No. 1 Juni 2015, Universitas Brawijaya

Pavlov, Steiner \& Wachter (2014), Real Estate Investment and Leverage : In Good Times and in Bad, Preprint submitted to AREUEA 22 April 2014.

Peter dan Yoseph. (2011). Analisis kebangkrutan dengan Metode z-score Altman, Springate dan Zmijewski pada PT. Indofood Sukses Makmur Tbk Periode 2005 2009. Akurat Jurnal IImiah Akuntansi 2(4).

RSD Purnomo, Cita Y Serfiani, Iswi Heriyani. 2013. Buku Pintar Investasi Properti. Jakarta: Gramedia Pustaka Utama PT.

Sopiyah Arini dan Triyonowati, (2013), "Analisis Altman Z-Score Untuk Memprediksi Kebangkrutan Pada Perusahaan Farmasi di Indonesia", Jurnal IImu \& Riset Manajemen Vol. 2 No. 11 (2013), Sekolah Tinggi Ilmu Ekonomi Indonesia (STIESIA) Surabaya.

Suad Husnan dan E. Pudjiastuti (2015) Dasar-dasar manajemen keuangan, edisi keenam, UPP STIM YKPN. ISBN. 979-8170-35-0, Yogyakarta

Suad Husnan dan E. Pujiastuti (2015). Dasar-dasar Manajemen Keuangan), edisi keenam, UPP STIM TKPN, Yogyakarta

Suburmayam KR, Wild John J.(2014). Financial Statetment Analysis 10 $0^{\text {th }}$ Edition. Diterjemahkan oleh: Dewi Yanti. 2014. Analisis Laporan Keuangan. Jakarta: Salemba Empat.

Suci Kurniawati (2016), "Analisis Kebangkrutan dengan Model Altman Z-Score Pada Perusahaan Subsektor Logam \& Sejenisnya di BEI Periode 2014", Seminar Nasional Cendekiawan 2016, Sekolah Tinggi Ilmu Ekonomi Indonesia Rawamangun

Sugiyono. (2012) Metodologi Penelitian Kuantitatif Kualitaif dan $R$ \& D. Cetakan ke17. Bandung: Alfabeta CV

Suprapto dan Nandan Limakrisna (2013), Petunjuk praktis penelitian ilmiah untuk menyususn skripsi, tesis, dan disertasi, Edisi 3, Penerbit mitra wacana media,2013.

Thian Cheng Lim (2012), Capital Structure of Real Estate Firms in Chinese Stock Market, International Journal of Management Sciences and Business Research Volume 1, Issue 9 2012- ISSN (2226-8235).

Van Horne, JC. \& Wachowicz JM.(2012). Fundamental of Financial Management $13^{\text {th }}$ Edition. Diterjemahkan oleh: Quratul'ain Mubarakah. 2012. Prinsip-prinsip Manajemen Keuangan. Jakarta: Salemba Empat. 